\begin{tabular}{|c|c|c|}
\hline & Int.J.Curr.Microbiol.App.Sci (2021) 10(09): 407-410 & \\
\hline & $\begin{array}{l}\text { International Journal of Current Microbiology and Applied Sciences } \\
\text { ISSN: 2319-7706 Volume } 10 \text { Number } 09 \text { (2021) } \\
\text { Journal homepage: http://www.ijcmas.com }\end{array}$ & 30 \\
\hline $\begin{array}{l}\text { EXCELLENT } \\
\text { PUBLISHERS }\end{array}$ & & www.ijemas.com \\
\hline
\end{tabular}

Original Research Article https://doi.org/10.20546/ijcmas.2021.1009.047

\title{
Fungal Flora Isolated from Deteriorating Card Board and Corrugated Box Samples in Thane and Bhiwandi, India
}

\author{
Asba Ansari ${ }^{1^{*}}$ and Moses Kolet ${ }^{2}$ \\ ${ }^{1}$ Department of Biotechnology, G.M. Momin Women's College, Bhiwandi, 421 302, India \\ ${ }^{2}$ Department of Botany, B.N. Bandodkar College of Science (Autonomous), Chendani, \\ Thane 400601, India \\ *Corresponding author
}

Keywords

Mycoflora,

corrugated boxes,

cardboard,

biodeterioration

Article Info

Accepted:

15 August 2021

Available Online:

10 September 2021

\section{A B S T R A C T}

Many cellulose based articles have found their way into human requirements and have become articles of necessity, paper being one such article. Card board and corrugated boxes are used as packing materials universally and alike paper, these are vulnerable to invasion by cellulose degrading fungi. The study in regions of Thane and Bhiwandi cities on the outskirts of Mumbai city in Western coastal part of Maharashtra, India focused on the invasion of cardboard and corrugated paper boxes by fungi. Twenty four species of fungi belonging to 11 genera were found on the deteriorating card board and corrugated paper samples during the study, prominent amongst them being the genus Aspergillus, Chaetomium, Curvularia, Trichoderma, Penicillium, Alternaria and five other cellulolytic fungal genera. Growth of fungi resulted in crumbling of the cardboard at places due to loss of strength. Many of the fungal forms isolated were potential health hazards which was cause for concern.

\section{Introduction}

Fungi have received attention in recent years, especially after fungal infections came into limelight during COVID-19 and post COVID19. Although plenty of studies and surveys have been carried out the true extent of fungal diversity is still not fully known and is expected to be much more than what is known today (Hawksworth, 2001). Apart from taxonomic placement, fungi are also divided into functional groups and one such group with social and environmental relevance is cellulose degrading fungi. Several cellulose based articles having found their way into human civilizations have become articles of necessity. Paper is one such article. Card board and corrugated boxes, derivative 
products of the paper industry, have found universal utility as an economical packaging material. Both these cellulosic materials, like paper, are vulnerable to invasion by this consistent group of cellulose degrading fungi, which bring about deterioration of cellulosic materials.

The present study was initiated to conduct a study of cellulose degrading fungi inhibiting cardboard and corrugated paper box samples from cartons used for packaging cutlery, printing papers and other utilities in Mumbai region of Western India. Mumbai is the commercial capital of India and the cities of Thane and Bhiwandi are situated on its outskirts. Both cities, like Mumbai are situated in coastal region of western part of Maharashtra state, India. While Thane is known as the 'lake city', Bhiwandi is famous as the 'Manchester of India' due to its thriving power loom industry. The entire region has a huge demand for paper, cardboard and corrugated packing materials. A survey of literature revealed scattered and scanty literature on fungal organisms invading card board in the areas of study which influenced the study.

\section{Materials and Methods}

Samples of cardboard and corrugated boxes showing few signs of deterioration were collected from Thane and Bhiwandi areas in Western parts of Maharashtra state from JuneSeptember 2020. The samples were as follows:

Sample No. 1. Cardboard cover of long book register stored in closed dark loft showing signs of dampness during monsoon.

Sample No. 2. Corrugated paper sample from corrugated box used for packaging and storing cutlery. The samples after collection were stored in sterilized polythene bags at room temperature for further processing. Both the samples showed few visible signs of deterioration. Serial dilution method (Pramer and Schmidt, 1966) was used for isolation of pure cultures of fungal organisms from the samples. Suspensions from the samples were diluted up to $10^{-5}$ and $1 \mathrm{ml}$ each of the respective dilutions was plated on nutrient medium (Czapex Dox Agar, Czapex Dox Agar with cellulose, PDA) in separate petri plates. The plates were incubated at room temperature for expression of fungal growth. Streptomycin $\left(50 \mathrm{mgl}^{-1}\right)$ was added to suppress bacterial growth and contamination. The isolated fungi were identified using standard literature and the standard system of fungal classification.

\section{Results and Discussion}

The different fungal organisms isolated from the cardboard and corrugated paper box samples are depicted in Table 1. Twenty four species of fungi belonging to 11 genera were found on the paper samples during the study. The sample No. 1 viz. cardboard cover of long book register yielded the maximum number of fungal forms followed by the second sample.

The typically dark, humid conditions of storage in the loft, accompanied by dampness during monsoon apparently contributed to the high number of fungi encountered on this sample. Prominent among the isolates was the genus Aspergillus with 7 species, followed by Chaetomium and Curvularia with 3 species each; Trichoderma, Penicillium and Alternaria with 2 species each and the rest of the genera represented by a single species. Aspergillus, Chaetomium, Alternaria and Memnoniella were encountered on both the samples. 
Table.1 Fungal forms isolated from the samples

\begin{tabular}{|c|c|c|c|c|c|}
\hline \multirow[t]{2}{*}{ No. } & \multirow[t]{2}{*}{ Fungal Organism } & \multirow[t]{2}{*}{$\begin{array}{l}\text { No. of } \\
\text { Isolates }\end{array}$} & \multicolumn{2}{|c|}{$\begin{array}{l}\text { Isolated from } \\
\text { sample }\end{array}$} & \multirow{2}{*}{$\begin{array}{c}\text { Total } \\
\text { presence } \\
\text { (No. of } \\
\text { samples) }\end{array}$} \\
\hline & & & 1 & 2 & \\
\hline 1 & Mucor sp. & 1 & + & & 1 \\
\hline 2 & Chaetomium globosum Kunze & 3 & + & + & 2 \\
\hline 3 & Chaetomium olivaceum Cooke \& Ellis & 2 & & + & 1 \\
\hline 4 & Chaetonium crispatum Fuckel & 1 & + & & 1 \\
\hline 5 & Trichoderma pseudokoeningii Rifai & 1 & + & & 1 \\
\hline 6 & Trichoderma viride Pers. & 1 & + & & 1 \\
\hline 7 & Aspergillus fumigatus Fresenius & 4 & + & + & 2 \\
\hline 8 & Aspergillus nidulans $\mathrm{G}$ Winter & 1 & + & & 1 \\
\hline 9 & Aspergillus sydowii Thom \& Church & 1 & + & & 1 \\
\hline 10 & Aspergillus flavus Link & 5 & + & + & 2 \\
\hline 11 & Aspergillus terreus Thom & 3 & + & + & 2 \\
\hline 12 & Aspergillus niger van Tieghem & 7 & + & + & 2 \\
\hline 13 & Aspergillus tamari Kita & 4 & + & + & 2 \\
\hline 14 & Penicillium citrinum Thom, $\mathrm{C}$ & 2 & & + & 1 \\
\hline 15 & Penicillium digitatum Pers. (Sacc.) & 1 & + & & 1 \\
\hline 16 & Paecilomyces varioti Bainier & 1 & + & & 1 \\
\hline 17 & $\begin{array}{l}\text { Memnoliella echinata (Rivolta) } \\
\text { Galloway }\end{array}$ & 2 & + & + & 2 \\
\hline 18 & $\begin{array}{l}\text { Cladosporium cladosporioides (Fresen) } \\
\text { G.A. de Vries }\end{array}$ & 1 & + & & 1 \\
\hline 19 & Curvulata lunata (Wakker) Boedjin & 1 & + & & 1 \\
\hline 20 & Curvularia pallescens Boedjin & 1 & + & & 1 \\
\hline 21 & Curvularia brachyspora (Boedjin) & 1 & + & & 1 \\
\hline 22 & Alternaria alternata (Fr.) Keissi & 2 & + & + & 2 \\
\hline 23 & Alternaria solani Sorauer & 1 & + & & 1 \\
\hline 24 & Non sporulating mycelium & 1 & + & & 1 \\
\hline
\end{tabular}

The findings are in agreement with those of Dawar et al., 2015. The genus Aspergillus dominated the fungal flora which is a fairly common phenomenon (Das and Prasad, 1996). Growth of fungi resulted in symptoms such as crumbling of the cardboard at places due to loss of strength. This is in conformity with symptoms reported by Dhawan and Garg (1993). Many of the fungal forms isolated were potential health hazards by virtue of their capability to cause allergic reactions (Crameri et al., 2014) or as pathogens (English 1980) which was ample cause for concern.

\section{Acknowledgements}

The authors wish to thank the Vidya Prasarak Mandal, Thane and Konkan Muslim Education Society, Bhiwandi (Dist. Thane) for the facilities provided for completion of this work.

\section{References}

Crameri, R., Garbani, M., Rhyner, C. and Huitema, C. 2014. Fungi: The neglected allergenic sources. Allergy 
69(2): 176-185.

English, M. P. 1980. Medical Mycology. Edward Arnold Publishers Ltd.

Das, M. K. L. and J. S. Prasad. 1996. Mycoflora in papers and boards of various origin. J. Indian bot. Soc. 75 : 307-308.

Dawar, S., Tariq, M. and Sultan F. 2015. Fungal deterioration of cellulosic materials. Int. J. Biol. Res., 3(1): 3-5

Dhawan, S. and Garg, K. L. 1993. Fungal deterioration of paper materials. In: Fungal Ecology and Biotechnology (Eds. B. Rai, D. K. Arora, N. K. Dubey and P. D. Sharma). Rastogi Publications, Meerut, India. pp. 119128.

Hawksworth, D. L. 2001. The magnitude of fungal diversity: The 1.5 million species estimate revisited. Mycol. Res. 105: 1422-1432.

\section{How to cite this article:}

Asba Ansari and Moses Kolet. 2021. Fungal Flora Isolated from Deteriorating Card Board and Corrugated Box Samples in Thane and Bhiwandi, India. Int.J.Curr.Microbiol.App.Sci. 10(09): 407-410. doi: https://doi.org/10.20546/ijcmas.2021.1009.047 